\title{
Genetic Control on Morphoagronomic Traits in Snap Bean
}

\author{
Marlon Peres da Silva, Antônio Teixeira do Amaral Júnior*, Rosana Rodrigues, Messias \\ Gonzaga Pereira and Alexandre Pio Viana \\ Laboratório de Melhoramento Genético Vegetal; Centro de Ciências e Tecnologias Agropecuárias; Universidade \\ Estadual do Norte Fluminense Darcy Ribeiro; Av. Alberto Lamego, 2000; Parque Califórnia; 28013-600; \\ amaraljr@uenf.br; Camposdos Goytacazes - RJ - Brazil
}

\begin{abstract}
Five divergent snap bean accessions from the vegetables germplasm bank at UENF and their ten diallel hybrids were evaluated to inheritance on five morphoagronomic traits using Hayman's methodology (1954). The results showed that additive effects were predominant for pod weight per plant, number of seeds per pod, height of the insertion of the first pod and number of days to flowering while non-additive effects were more important for number of pods per plant. The best strategy to be adopted was the use of these acessions in an intrapopulation breeding program aiming the obtaintion of superior segregants. For pod numbers the indicated strategy would be an interpopulational breeding procedure, to exploite the heterosis related to the non-additive effects. The analysis also revealed that dominant alleles increased the number of pods per plant, pod weight per plant and number of seeds per pod. Allelic interaction was overdominance to the number of pods per plant, while the partial dominance controled the expression of other traits.
\end{abstract}

Key words: Snap bean, Phaseolus vulgaris, diallel analysis, inheritance

\section{INTRODUCTION}

Planning and execution of a breeding program require information on the genetic systems controlling the characters of the interest, so that the expected gains can be maximized with use of the selection process (Vencovsky and Barriga, 1992; Barelli et al., 1999; Viana et al., 1999). In snap bean, studies about inheritance of important morphoagronomic traits for plant breeders are scarce. Besides, there are controversial results considering the same traits. Rodrigues et al. (1998), as an example, found that dominance effects were more important for plant height while additive effects were superiors for pod length. Leal et al. (1979), studying a partial diallel in snap bean, in order to investigate genetic effects over yield traits, comparing performance on $\mathrm{F}_{5}$ and $\mathrm{F}_{6}$ with $F_{1}$ and $F_{2}$, concluded that additivity and epistasis were predominant for pod lenght, yield per plant, number of pods per plant, individual pod weight, number of pods per plant, and incidence of interlocular cavitation. Carvalho et al. (1999), studying, tested four snap bean cultivars (Alessa, Andra, Cota and Cascade) as parents in a diallel design without reciprocals, and verified significance for all traits considering specific combining ability, indicating that epistatic and, or dominance effects were involved in genetic control for number of pods, pod diameter, pod length and number of days to flowering.

Considering different crops, the diallel analysis has been emphasized in many breeding programs because of the large amount of information this

*Author for correspondence 
approach can offer to the breeder (Foolad and Bassiri, 1983; Amaral Júnior et al., 1996; Barelli et al., 1999; Cruz and Regazzi, 2001). According to Cruz and Regazzi (2001), Hayman's procedure (1954), among methodologies of diallel analysis available, has greatly contributed to breeding. It provides an efficient study of the genetic action involved in the control of traits and identifies the presence of epistatic interactions. It also estimates the genetic component of genotype determination and the limit of selection which may be obtained from assessed parents. The present study was carried out using a diallel cross system based on Hayman's methodology (1954) among five divergent snap bean accessions to obtain genetic information for morphoagronomic traits to start a breeding program.

\section{MATERIALS AND METHODS}

Parents and hybrids: The snap bean accessions UENF 1429, UENF 1432, UENF 1442, UENF 1445 and UENF 1448, from the vegetable germoplasm bank at UENF (Darcy Ribeiro North Fluminense State University), Rio de Janeiro, Brazil, were chosen because of their divergent morphological and agronomic traits identified by Abreu (2001) and used as parents in a complete diallel without reciprocals. Crosses were made using the method proposed by Vieira (1967), which consisted of mechanical emasculation of the female parent using tweezers on flower buds one day before flowering followed by crosses pollination. Ripe pollen from open flowers of the male parents was used to perform the crosses. The hybrids were confirmed by flower color and RAPD markers.

The following traits were evaluated: a) mean number of pods per plant (MNP), obtained from the ratio between the total number of pods and the total number of plants, in each treatment; b) mean pod weight per plant (MPW), expressed in grams, obtained from the ratio between the total weight of pods and the total number of plants, in each treatment; c) mean number of seeds per pod (MNS), obtained from the average number of seeds in a sample of ten pods per plant, in each treatment; d) mean height of the insertion of the first pod (HFP), expressed in $\mathrm{cm}$, as the ratio between the measurement from the soil to the insertion of the first pod and the respective number of plants in each treatment; and e) number of days to flowering (NDF), obtained by counting the number of days, from sowing to the complete opening of the first flower.

Treatments and experimental design: The populations of five parents and $10 \mathrm{~F}_{1}$, totalizing 15 treatments were assessed in the greenhouse at the UENF, Campos dos Goytacazes, Rio de Janeiro, in 2002. The experimental design was a randomized complete block with fifteen replications. Two seeds were sown in $5 \mathrm{dm}^{3}$ pot containing substrate. They were thinned fifteen days after emergence, and one plant was left in each pot. Each pot with one plant made up an experimental unit.

An analysis of variance considering randomized complete block design for the data of each characteristic was carried out, using GENES program (Cruz, 2001). The value of each observation provided by the following statistical model, considering accession as fixed effect was used:

$Y_{i j k}=\mu+A_{i}+B_{j}+\xi_{i j k}$

where $Y_{i j k}=$ observation of $\mathrm{i}^{\text {th }}$ treatment in the $\mathrm{j}^{\text {th }}$ block ( $i=1,2, \ldots, \quad a=15 ; j=1,2, \ldots, b=15)$; $\mu=$ general mean; $A_{i}=$ effect of the $\mathrm{i}^{\text {th }}$ access; $B_{j}=$ effect of the $\mathrm{j}^{\text {th }}$ block and $\xi_{i j k}=$ experimental error.

Hayman's diallel analysis (1954): The Hayman`s diallel analysis (1954) was carried out based on Cruz and Regazzi (2001), considering that homozygous parents were different in only one locus $(\mathbf{T} / \mathbf{t})$, and present desirable alleles in an $\mathbf{u}_{\mathbf{1}}$ ratio and undesirable alleles in a $\mathbf{v}_{\mathbf{1}}$ ratio. The GENES program (Cruz, 2001) was used for this analysis.

\section{RESULTS AND DISCUSSION}

Sufficiency test of the additive-dominant model: Assuming that the genetic effects are the results of the additive and dominant action of genes, Hayman (1954) imposed a series of restrictions which required the application of tests to verify the sufficiency of the model. Table 1 shows the results of the applications of two tests for the traits assessed. The totality of the traits was no significant in test $\mathrm{F}$, hence the assumptions imposed were valid and indicated that the additive- 
dominant model was adequate to the genetic study of these traits.

Mean number of pods per plant (MNP): Table 2 shows the correlation between the genotypic values of the $\mathrm{i}^{\text {th }}$ parents $\left(\bar{y}_{i i}\right)$ and the sum of the covariance and variance among means of the $i^{\text {th }}$ lines $\left(\hat{W}_{i}+\hat{V}_{i}\right)$ and the expected values of the coordinates $\hat{W}_{R}, \hat{V}_{R}$ and $\hat{W}_{D}, \hat{V}_{D}$ and their sums. There was a negative correlation between $\bar{y}_{i i}$ and
$\left(\hat{W}_{i}+\hat{V}_{i}\right)$, of magnitude equal to -0.8322 , showing that the alleles which acted to increase the number of pods per plant were predominantly dominant. In this case, parents UENF 1448, UENF 1429 and UENF 1432, which were closer to the dominant end of the regression of $\hat{W}_{i}$ over $\hat{V}_{i}$ (Fig. 1) would be suitable for selection of earlier lines.

Table 1 - Sufficiency tests of the additive-dominant model, using Hayman's methodology (1954) for five traits among five snap bean parents

\begin{tabular}{lrc}
\hline \multirow{2}{*}{ Traits $^{\mathbf{1 /}}$} & Regression $^{2 /}$ & ${\text { Rotation of the } \hat{W}_{i} \text { and } \hat{V}_{i} \text { axle }^{3 /}}^{\text {3/ }}$ \\
\cline { 2 - 3 } & $\mathbf{t}\left(\mathbf{H}_{\mathbf{0}} \mathbf{:} \mathbf{b}=\mathbf{1}\right)$ & $\mathbf{F}=\mathbf{t}^{\mathbf{2}}\left(\mathbf{H}_{\mathbf{0}} \mathbf{:} \mathbf{B}=\mathbf{b} \mathbf{- 1}=\mathbf{0}\right)$ \\
\hline MNP & $-2,4878 \mathrm{~ns}$ & $1,5204 \mathrm{~ns}$ \\
MPW & $0,0980 \mathrm{~ns}$ & $-0,4087 \mathrm{~ns}$ \\
MNS & $0,0745 \mathrm{~ns}$ & $-0,4603 \mathrm{~ns}$ \\
HFP & $-0,9487 \mathrm{~ns}$ & $0,6789 \mathrm{~ns}$ \\
NDF & $-0,2790 \mathrm{~ns}$ & $0,0796 \mathrm{~ns}$ \\
\hline
\end{tabular}

${ }^{\pi} \mathrm{MNP}=$ mean number of pods per plant; $\mathrm{MPW}=$ mean pod weight per plant; $\mathrm{MNS}=$ mean number of seeds per pod; HFP = mean height of the insertion of the first pod; and $\mathrm{NDF}=$ number of days to flowering.

${ }^{2 /} \mathrm{t}$ test, weighing the $\hat{W}_{i}+\hat{V}_{i}$, values, at $5 \%$ levels of probability.

${ }^{3 /} \mathrm{F}$ test, weighing the $\hat{W}_{i}$ and $\hat{V}_{i}$ axles by their $45^{\circ}$ rotation, at $1 \%$ and $5 \%$ levels of probability. ns $=$ not significant at $1 \%$ and $5 \%$ levels of probability.

Fig. 1 shows the possibility of obtaining even more dominant segregant material; for instance, although parent number UENF 1448 had the greatest concentration of dominant alleles which was $\hat{W}_{i}+\hat{V}_{i}=9.8486$ (Table 3 ), its value was still lower than its potential of -3.6209 , according Table 2. However, the opportunity of obtaining these segregant materials should be cautiously evaluated, because of the low value of the genotypic determination coefficient $\left(\tilde{h}_{R}^{2}\right)$, equal to 0.3454 (Table 4) that indicated the low reliability of accessions in transmiting the desirable phenotype to future generations.

Table 2 - Estimates of the correlation between the genotypic value of the $\mathrm{i}^{\text {th }}$ parents $\left(\bar{y}_{i i}\right)$ and the sum of the covariance with the variance among means of the $\mathrm{i}^{\text {th }}$ line $\left(\hat{W}_{i}+\hat{V}_{i}\right)$ and the expected values of the coordinates $\hat{W}_{R}, \hat{V}_{R}$ and $\hat{W}_{D}, \hat{V}_{D}$ and the sum of these for five traits assessed in five snap bean parents, according to Hayman's methodology (1954)

\begin{tabular}{lccccccc}
\hline \multirow{2}{*}{ Traits $^{1 /}$} & \multicolumn{7}{c}{ Estimates values } \\
\cline { 2 - 8 } & $\mathbf{r}\left(\bar{y}_{i i}, \hat{W}_{i}+\hat{V}_{i}\right)$ & $\hat{W}_{R}$ & $\hat{V}_{R}$ & $\hat{W}_{R}+\hat{V}_{R}$ & $\hat{W}_{D}$ & $\hat{V}_{D}$ & $\hat{W}_{D}+\hat{V}_{D}$ \\
\hline MNP & -0.8322 & 38.0532 & 94.4739 & 132.5271 & -5.8654 & 2.2445 & -3.6209 \\
MPW & -0.9493 & 12.9972 & 10.2068 & 23.2040 & -3.2248 & 0.6283 & -2.5965 \\
MNS & -0.8314 & 77.9202 & 72.5214 & 150.4414 & 4.2294 & 0.2136 & 4.4430 \\
HFP & 0.7128 & 118.1981 & 126.2124 & 244.4105 & 9.2151 & 0.7671 & 9.9822 \\
NDF & 0.8817 & 31.8872 & 27.9179 & 59.8051 & 5.8993 & 0.9555 & 6.8548 \\
\hline
\end{tabular}

${ }^{1 /} \mathrm{MNP}=$ mean number of pods per plant; MPW = mean pod weight per plant; MNS = mean number of seeds per pod; HFP = mean height of the insertion of the first pod; and NDF = number of days to flowering. 
Table 3 - Values of the sum of the covariance between parent means and means of the $\mathrm{i}^{\text {th }}$ line $\left(\hat{W}_{i}+\hat{V}_{i}\right)$ with the variance between means of the $\mathrm{i}^{\text {th }}$ line $\hat{V}_{i}$ for five traits ${ }^{1 /}$ assessed in five snap bean parents

\begin{tabular}{lccccc}
\hline \multirow{2}{*}{ Parents } & \multicolumn{5}{c}{$\hat{W}_{i}+\hat{V}_{i}$} \\
\cline { 2 - 5 } & MNP & MPW & MNS & HFP & NDF \\
\hline UENF 1429 & 17.3123 & 11.5195 & 43.7494 & 98.2866 & 60.2803 \\
UENF 1432 & 21.5841 & 12.4184 & 117.6309 & 170.0230 & 50.0913 \\
UENF 1442 & 67.3438 & 21.7684 & 101.8298 & 169.7995 & 38.9053 \\
UENF 1445 & 89.3042 & 17.4797 & 95.1689 & 98.3359 & 67.2803 \\
UENF 1448 & 9.8486 & 2.4278 & 94.1272 & 30.9895 & 8.7141
\end{tabular}

${ }^{1 /} \mathrm{MNP}=$ mean number of pods per plant; MPW = mean pod weight per plant; MNS = mean number of seeds per pod; HFP = mean height of the insertion of the first pod; and NDF = number of days to flowering.

Table 4 shows the predominance of the dominant genetic effects (since $\tilde{D}-\tilde{H}_{1}=$ -82.8168). Therefore, using heterosis effects could give superior gains to this trait. The estimates of the mean degree of dominance (2.8923), indicated that overdominance effects were responsible for allelic interaction verified in this study. Average ratio of dominants and recessives genes number, $\tilde{K}_{D} / \tilde{K}_{R}$, was 0.7697 (Table 4), and indicated allelic symmetry, which was confirmed by the value of $\tilde{H}_{2} / 4 \tilde{H}_{1}$ estimative, near 0.25 .

Mean pod weight per plant (MPW): The high negative correlation value (-0.9493) between $\bar{y}_{i i}$ and $\left(\hat{W}_{i}+\hat{V}_{i}\right)$ showed that the dominant alleles were the responsible for the increase in the mean pod weight per plant (Table 2).

Fig. 2 shows that accession UENF 1448 had the greatest concentration of dominant genes. Considering that the maximum value for the parental $\hat{W}_{D}+\hat{V}_{D}$ sum was -2.5965 (Table 2 ), it was possible to obtain desirable pure lines, with higher weight of pods, since parent UENF 1448 showed a value for $\hat{W}_{i}+\hat{V}_{i}=2.4278$ (Table 3 ). This was ratified by the predominance of the additive effects over the dominance $\left(\tilde{D}-\tilde{H}_{1}=\right.$ 11.3028), and also by the high value of the genotypic determination coefficient $\left(\tilde{h}_{R}^{2}=\right.$ 0.8881 ) expressed for this trait (Table 4).

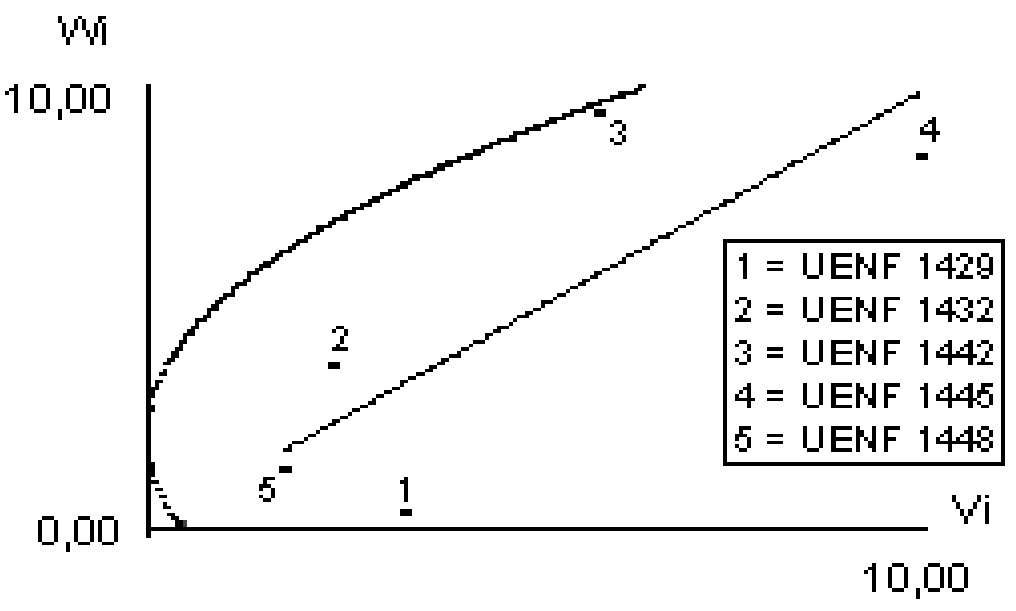

Figure 1 - Regression of $\hat{W}_{i}$ over $\hat{V}_{i}$ for mean number of pods per plant. 
Table 4 - Estimates of the genetic component and informations for the assessed traits, according to Hayman's methodology (1954)

\begin{tabular}{lccccc}
\hline & \multicolumn{5}{c}{ Estimates of genetic component $^{2 /}$ and informations $^{\mathbf{3} /}$} \\
\cline { 2 - 6 } Traits $^{\mathbf{1}}$ & $\tilde{D}-\tilde{H}_{1}$ & $\sqrt{\tilde{H}_{1} / \tilde{D}}$ & $\tilde{H}_{2} / 4 \tilde{H}_{1}$ & $\tilde{K}_{D} / \tilde{K}_{R}$ & $\tilde{h}_{R}^{2}$ \\
\hline MNP & -82.8168 & 2.8923 & 0.2301 & 0.7697 & 0.3454 \\
MPW & 11.3028 & 0.5567 & 0.1730 & 1.1499 & 0.8881 \\
MNS & 47.4605 & 0.6054 & 0.1375 & 0.4575 & 0.8280 \\
HFP & 68.2692 & 0.4984 & 0.0461 & 0.4804 & 0.7713 \\
NDF & 17.6332 & 0.7162 & 0.1863 & 0.3278 & 0.9014 \\
\hline
\end{tabular}

${ }^{1 /} \mathrm{MNP}=$ mean number of pods per plant; $\mathrm{MPW}=$ mean pod weight per plant; MNS = mean number of seeds per pod; HFP = mean height of the insertion of the first pod; and NDF = number of days to flowering.

2/ $\tilde{D}-\tilde{H}_{1}=$ component which expresses the difference between the additive and dominant effects.

${ }^{3 /} \sqrt{\tilde{H}_{1} / \tilde{D}}=$ mean degree of dominance; $\tilde{H}_{2} / 4 \tilde{H}_{1}$ and $\tilde{K}_{D} / \tilde{K}_{R}=$ allelic symmetry; and $\tilde{h}_{R}^{2}=$ narrow sense genotypic determination coefficient.

Table 4 shows the presence of the partial dominance for the allelic relation because of the value 0.5567 for the mean degree of dominance. Hence, it would be more difficult selecting superior individuals since heterozygous would be almost so valuable than recessive homozygous.
Based on value 1.1499 , revealed by $\tilde{K}_{D} / \tilde{K}_{R}$, there was allelic symmetry between dominant and recessive alleles, which could be observed in Fig. 2.

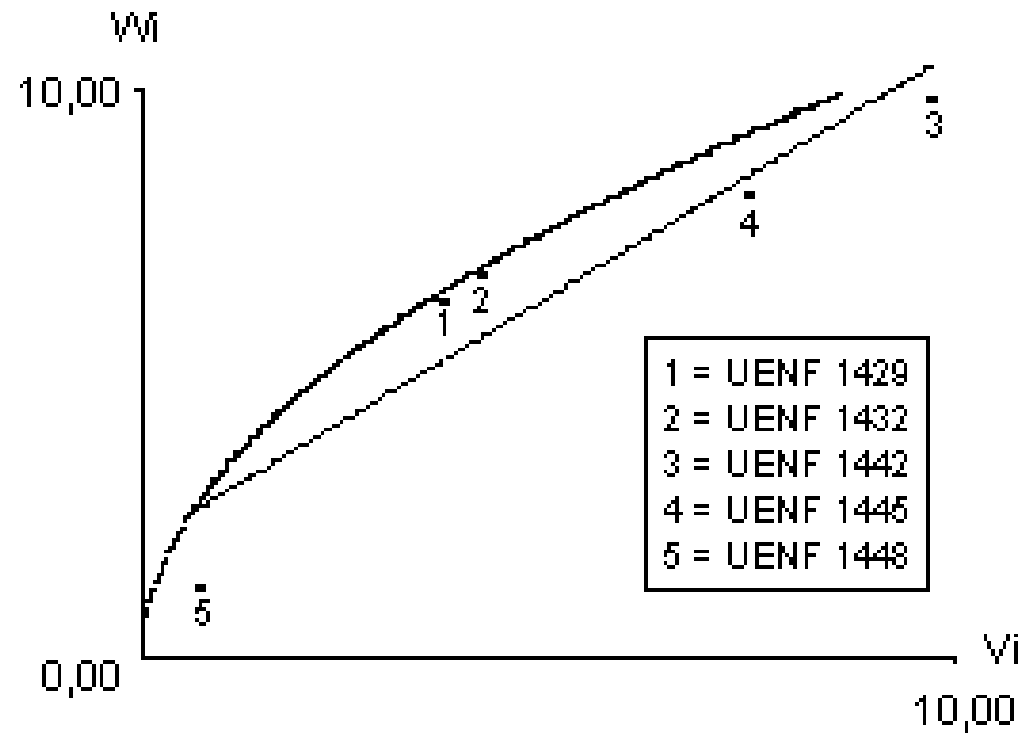

Figure 2 - Regression of $\hat{W}_{i}$ over $\hat{V}_{i}$ for mean pod weight per plant.

Mean number of seeds per pod (MNS): Similarly to the mean number of pods per plant and mean pod weight per plant, the dominant alleles contributed mainly to an increase in the number of seeds per pod, as indicated by the correlation value for $\bar{y}_{i i}$ and $\left(\hat{W}_{i}+\hat{V}_{i}\right)$ found for this trait $(-0.8314)$, (Table 2). Based on Fig. 3, the rank of the parents in terms of concentration of dominant alleles was 1 (UENF 1429), 5 (UENF 1448), 4 (UENF 1445), 3 (UENF 1442) and 2 (UENF 1432). Therefore, 
parent UENF 1429 would be indicated for using in breeding programs to obtain superior gains for number of seeds per pod. This was supported by the high value of the genotypic determination coefficient $\left(\tilde{h}_{R}^{2}=0.8280\right)$ expressed for this trait
(Table 4). Because of the high magnitude of $\tilde{h}_{R}^{2}$, it could be inferred that simple selection methods could reach satisfactory results in terms of number of seeds per pod.

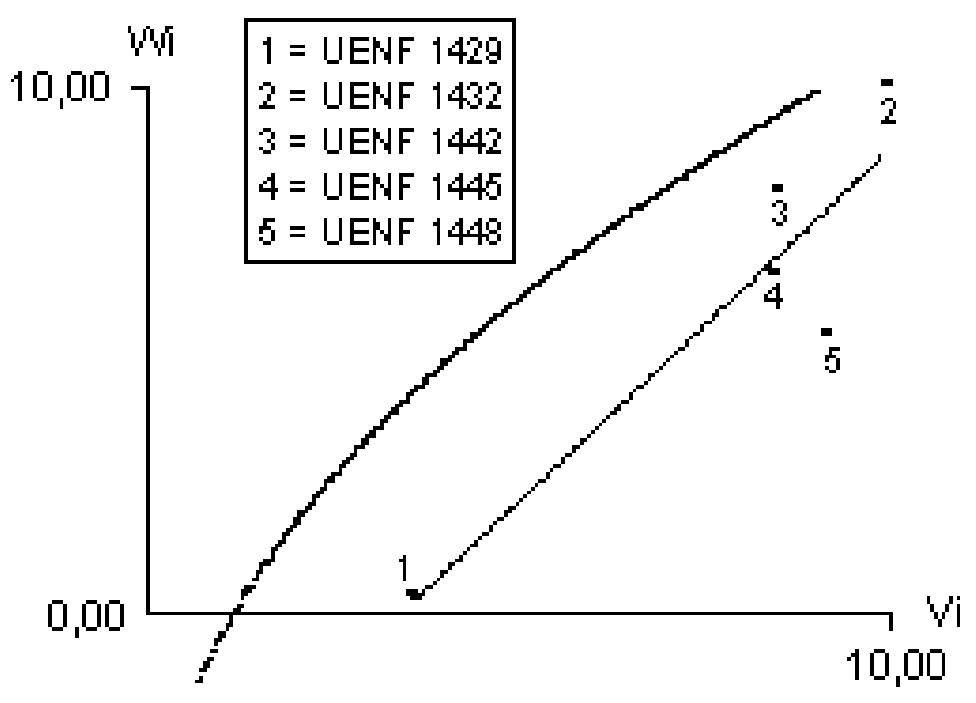

Figure 3 - Regression of $\hat{W}_{i}$ over $\hat{V}_{i}$ for mean number of seeds per pod.

Mean height of the insertion of the first pod (HFP): There was a positive correlation between $\bar{y}_{i i}$ and $\left(\hat{W}_{i}+\hat{V}_{i}\right)$, of magnitude equal to 0.7128 , showing that the alleles which increased the height of the insertion of the first pod were predominantly recessives (Table 2 ). In a breeding program aiming to develop snap bean cultivars with small height of first pod insertion in order to increase the number of harvest per year, it must be considered that dominant alleles were desirable to obtain genetic gains in advanced generation. However, it must be considered yet that reducing the height of the first pod insertion could result in yield losses because of the pod contact with pathogen present in soil and soil humidity.

The parent with higher concentration of dominant alleles was UENF 1448 (Table 3 and Fig. 4), presenting a value of 30.9895 (Table 3). Nevertheless, it was still possible to obtain materials with major concentration of dominant alleles, considering that the value of limit of selection was 9.9822 (Table 2) according to expression $\hat{W}_{i}+\hat{V}_{i}$ (Table 3). The opportunity to obtaining these materials became more evident because of the predominance of additive effects of genes $\left(\tilde{D}-\tilde{H}_{1}=68.2692\right.$, Table 4$)$ and the high heritability value $\left(\tilde{h}_{R}^{2}=0.7713\right.$, Table 4$)$, which ensured the success of the transmission of the desirable alleles to future generations.

Number of days to flowering (NDF): The major aim of a snap bean breeding program is to reduce the number of days to flowering and to obtain earlier cultivars and larger number of harvest per year, increasing farmers gain. In this case, the plant breeder is interested in alleles which reduces the magnitude of this character. Although the positive correlation between $\bar{y}_{i i}$ and $\left(\hat{W}_{i}+\hat{V}_{i}\right)$ was verified in this study, the dominant alleles were most interesting for breeding this character. The parent UENF 1448 (Fig. 5) presented a high concentration of dominance alleles $\left(\hat{W}_{D}+\hat{V}_{D}=\right.$ 8.7141, Table 3), overcoming the selection limit 
(6.8548) achieved by a breeding program as indicated in Table 2. Therefore, it was possible to obtain superior genotypes in earlier advanced generations, which was supported by high $\tilde{h}_{R}^{2}$ value for this trait (0.9014), showed in Table 4 . Moreover, the major importance of additive effects in this trait expression associated with the intralocus ratio near 1.000 (Table 4) indicated that probably breeding program for number of days to flowering could be successful.

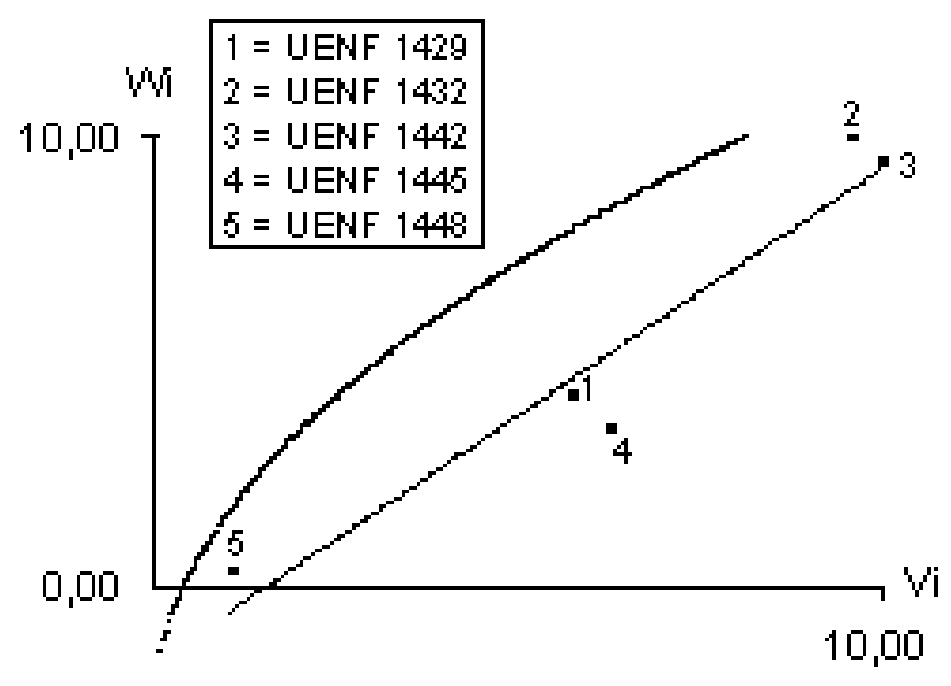

Figure 4 - Regression of $\hat{W}_{i}$ over $\hat{V}_{i}$ for mean height of the insertion of the first pod.

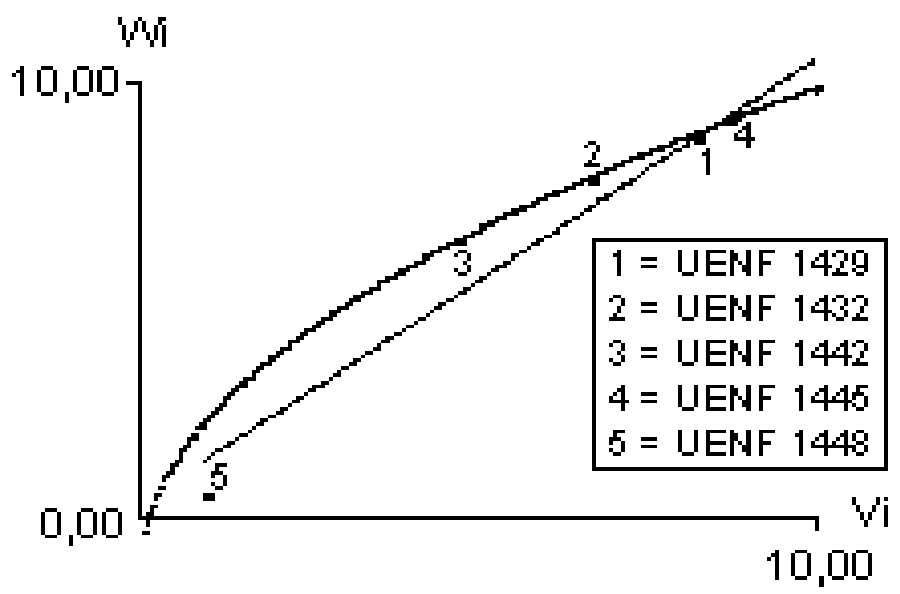

Figure 5 - Regression of $\hat{W}_{i}$ over $\hat{V}_{i}$ for number of days to flowering. 


\section{RESUMO}

Cinco acessos divergentes de feijão-de-vagem do banco de germoplasma da UENF, Rio de Janeiro, Brasil, e seus dez híbridos dialélicos possíveis, foram avaliados quanto à herança para cinco características morfoagronômicas, utilizando a metodologia de Hayman (1954). Os resultados evidenciaram que os efeitos gênicos aditivos foram predominantes para peso de vagem por planta, número de sementes por vagem, altura da inserção da primeira vagem e número de dias para florescimento, enquanto os efeitos gênicos não aditivos foram mais importantes na expressão de número de vagens por planta. Isso demonstra que, para as quatro primeiras características, a melhor estratégia a ser adotada é o uso dos acessos em programa de melhoramento intrapopulacional, visando a obtenção de segregantes superiores. Para número de vagens, a estratégia de melhoramento interpopulacional seria mais indicada, por explorar a heterose. Os resultados revelaram ainda que os alelos dominantes são responsáveis por aumentos no número de vagens por planta, no peso de vagem por planta e no número de sementes por vagem. A interação alélica de sobredominância destacou-se para número de vagens por planta, enquanto para as demais características houve a prevalência de dominância parcial.

\section{REFERENCES}

Abreu, F. B. (2001), Aplicação de técnicas de análise multivariada em acessos de feijão-de-vagem (Phaseolus vulgaris L.) de crescimento indeterminado do banco de germoplasma da UENF. Master's Thesis, UENF, Campos dos Goytacazes, RJ. Amaral Júnior, A. T.; Casali, V. W. D.; Scapim, C. A.; da Silva, D. J. H. and Cruz, C. D. (1996), Análise dialélica da capacidade combinatória de cultivares de tomateiro. Bragantia, 55, 67-73.

Barelli, M. A. A.; Gonçalves-Vidigal, M. C.; Amaral Júnior, A. T.; Vidigal Filho, P. S. and Silvério, L. (1999), Genetic control on number of days to flowering and yield components in common bean (Phaseolus vulgaris L.). Acta Scientiarum, 21, 423-427.

Carvalho, A. C. P. P.; Leal, N. R.; Rodrigues, R. and Costa, F. A. (1999), Capacidade de combinação para oito caracteres agronômicos em cultivares rasteiras de feijão-de-vagem. Horticultura Brasileira, 17, 102-105.

Cruz, C. D. (2001), Programa genes: aplicativo computacional em genética e estatística. Viçosa : UFV. pp. 394.
Cruz, C. D. and Regazzi, A. J. (2001), Modelos biométricos aplicados ao melhoramento genético. Viçosa : UFV. pp. 390.

Foolad, M. R. and Bassiri, A. (1983), Estimates of the combining ability reciprocal effects and heterosis for yield and yield components in a common bean diallel cross. J. Agric. Sci., 100, 103-108.

Hayman, B. I. (1954), The theory and analysis of diallel crosses. Genetics, 39 : 789-809.

Leal, N. R.; Hamad, I. and Bliss, F. (1979), Combining ability estimates for snap bean traits using early and advanced generations. HortScience, 14, 405-405.

Rodrigues, R.; Leal, N. R. and Pereira, M. G. (1998), Análise dialélica de seis características agronômicas em Phaseolus vulgaris L. Bragantia, 57, 241-250.

Vencovsky, R. and Barriga, P. (1992), Genética biométrica no fitomelhoramento. Ribeirão Preto : Sociedade Brasileira de Genética. pp. 486.

Viana, J. M. S.; Cruz, C. D. and Cardoso, A. A. (1999), Theory and analysis of partial diallel crosses. Genetics and Molecular Biology, 22, 591-599.

Vieira, C. (1967), O feijoeiro comum: cultura, doenças e melhoramento. Viçosa : Imprensa Universitária. pp. 220.
Received: May 16, 2003; Revised: October 21, 2003; Accepted: May 17, 2004. 